\title{
A new synonym, a new male description and new geographical records for three Ceraeochrysa species (Neuroptera: Chrysopidae)
}

\author{
FRANCISCO SOSA ${ }^{1} \&$ SERGIO DE FREITAS ${ }^{2}$ \\ ${ }^{\prime}$ Museo Entomológico “Dr. José Manuel Osorio” Universidad Centroccidental "Lisandro Alvarado”, Barquisimeto (UCOB), Venezu- \\ ela. PhD student at the Universidade Estadual Paulista, Jaboticabal, São Paulo, Brazil.E-mail fransodu73@hotmail.com \\ ${ }^{2}$ Universidade Estadual Paulista, Jaboticabal, São Paulo, Brazil.E-mail: serfre@fcav.unesp.br
}

\begin{abstract}
Ceraeochrysa Adams is the largest genus in Chrysopini with 62 valid species distributed in the New World. The taxonomy of this group is complex and largely based on male genitalic characters. There are still serious complications, especially with the species that have been described solely from female specimens. The male of $C$. montoyana (Navás, 1913), unknown previously, is herein described for the first time, and compared with its closest relative, C. claveri (Navás, 1911). Ceraeochrysa acutipuppis Adams \& Penny, 1985 is designated as a junior synonym of C. fairchildi (Banks, 1946) based on the evidence that both species share external morphological features uncommon in other species of the genus. The species $C$. claveri, C. fairchildi and C. montoyana are recorded from Venezuela for the first time. External morphology and genitalia of these insects are described and illustrated.
\end{abstract}

Key words: Chrysopinae, Chrysopini, green lacewing, predator, synonymy

\section{Resumen}

Ceraeochrysa Adams es el género más grande de Chrysopini con 62 especies válidas distribuidas en el Nuevo Mundo. La taxonomía de este grupo es compleja y está basada principalmente en caracteres de genitalia del macho. Aun existen controversias sobre el status de algunas especies, principalmente aquellas que fueron descritas a partir de un único ejemplar hembra. El macho de C. montoyana (Navás, 1913), previamente desconocido, es descrito por primera vez y comparado con el de la especie más cercana, C. claveri (Navás, 1911). Ceraeochrysa acutipuppis Adams \& Penny, 1985 es asignada como sinónimo menor de $C$. fairchildi (Banks, 1946) con base en que ambas especies comparten caracteres morfológicos externos no comunes en otras especies. Las especies $C$. claveri, $C$. fairchildi y C. montoyana son registradas para Venezuela por primera vez. La morfología externa y genitalia de estas especies son descritas e ilustradas.

Palabras clave: Chrysopinae, Chrysopini, crisopa, depredador, sinonimia

\section{Introduction}

Recently, Freitas et al. (2009) revised the New World genus Ceraeochrysa Adams. This work paved the way for new studies improving the taxonomic understanding of this group. Subsequently, Tauber \& Flint (2010) provided information to solve some inaccuracies in the revision and help resolve controversies regarding the status of some species. Currently, Ceraeochrysa contains 62 valid species (Freitas et al. 2009; Sosa \& Freitas 2010; Tauber \& Flint 2010). However, there remain serious complications, especially with the species that have been described solely from female specimens, namely C. acutipuppis Adams \& Penny, 1985; C. castilloi (Navás, 1913); C. caucana (Banks, 1910); C. dolichosvela Freitas \& Penny, 2001; C. fiebrigi (Navás, 1913); C. indicata (Navás, 1914); C. lateralis (Guerin-Méneville, 1844); C. reducta (Banks, 1944); and C. montoyana (Navás, 1913). The male of $C$. montoyana is herein described for the first time and compared with its closest relative, C. claveri (Navás, 1911). 